\title{
Effects of epibiotic bacteria on leaf growth and epiphytes of the seagrass Posidonia oceanica
}

\author{
D. Celdrán ${ }^{1, *}$, E. Espinosa ${ }^{2}$, A. Sánchez-Amat ${ }^{2}$, A. Marín ${ }^{1}$ \\ ${ }^{1}$ Departamento de Ecología e Hidrología, Facultad de Biología, Universidad de Murcia, 30100 Murcia, Spain \\ ${ }^{2}$ Departamento de Genética y Microbiología, Facultad de Biología, Universidad de Murcia, 30100 Murcia, Spain
}

\begin{abstract}
Beneficial effects of microorganisms on plant productivity are well known from terrestrial ecosystems, but no corresponding effects on marine plants have been described. We tested the hypothesis that the bacteria Marinomonas posidonica and M. mediterranea, which have been described as a forming component of the microbiota on Posidonia oceanica, influence leaf growth and epiphytic communities of this seagrass. We carried out 4 treatments: (1) seedlings inoculated with $M$. mediterranea or (2) M. posidonica and seedlings to which (3) sterilized seawater (sterile control) or (4) fresh seawater (field control) was added. Two experiments were performed: a growth assay in the laboratory under sterile conditions measuring leaf area after 3 mo, and an epiphyte assay in which the seedlings were transferred to the field. Leaves were sampled after 3 mo to analyse the community structure of epiphytes. The growth experiment showed that inoculation with $M$. posidonica enhanced leaf growth of $P$. oceanica compared with the controls to which no bacterial strain was added. In contrast, inoculation with $M$. mediterranea did not stimulate leaf growth. Likewise, inoculation with M. posidonica induced changes in epiphyte structure and can be expected to have a regulatory effect on macroepiphyte structure.
\end{abstract}

KEY WORDS: Marinomonas spp. · Viability · Microbiota $\cdot$ Epiphytic communities · Biofouling

\section{INTRODUCTION}

Specific microbe-plant associations play an important role in promoting plant production in terrestrial ecosystems. For example, Rhizobium spp. or Glomus spp. produce nitrogen-fixing nodules or arbuscular mycorrhizal fungi, respectively, which enhance plant growth in nutrient-limited soil (Avis et al. 2008). The ecological importance of these associations in terrestrial plants is such that Glomus spp. are obligate symbionts of $>80 \%$ of terrestrial plants (St-Arnaud et al. 1996, Selosse et al. 2006). Other microorganisms, such as Pseudomonas spp., indirectly assist plant productivity through the control of plant pathogens. In particular, Pseudomonas spp. have been widely studied for their ability to reduce the development of various soilborne plant pathogens (Carisse et al.
2003). Numerous modes of action have been reported for Pseudomonas spp., including the production of antimicrobial compounds (Thrane et al. 2000), competition (Ellis et al. 1999) or the induction of plant defence mechanisms (Ongena et al. 2000, 2002). The role of associations between bacteria and host plant surfaces in maintaining productivity of primary producers in marine ecosystems is, however, unknown.

Marine biofouling communities are complex, highly dynamic systems consisting of a wide range of organisms. Such communities develop with bacterial attachment followed by colonisation by higher organisms such as invertebrate larvae and algal spores (Richmond \& Seed 1991, Rodríguez et al. 1993, Maki 1999, Callow 2000). The initial phases of colonizing underdeveloped surfaces in the sea last 
from minutes to days. Bacteria become established in the first hour, diatoms during the first day and larval spores after $1 \mathrm{wk}$ (Wahl 1989).

Bacteria on the surface of living plants appear to form spatially structured, host-specific and relatively stable communities during the life-span of their host (Bhadury \& Wright 2004, Pasmore \& Costerton 2003, Egan et al. 2008). Competition between bacteria, the ability to resist grazing, and host-derived factors such as surface-localized secondary metabolites are some of the factors likely to determine the final surface community (Givskov et al. 1996, Manefield et al. 2001, Matz \& Kjelleberg 2005, Rao et al. 2005, Egan et al. 2008). In terms of chemical ecology, it seems likely that some strains of epibiotic bacteria on living surfaces play a 'protective' role, releasing chemicals that prevent biofouling by other organisms (Armstrong et al. 2001, Rao et al. 2005). Studies on different bacterial species have underlined the importance of exopolymeric substances for the activation or inhibition of macrofouling settlement (Young \& Mitchell 1973), suggesting that initial bacterial composition would have a cascading effect on the structure of the epiphyte community, although this aspect remains unexplored.

Leaves and rhizomes of Posidonia oceanica (L.) Delile offer suitable substrata for the settlement and growth of a number of epiphytic organisms that form stratified multi-species assemblages (Mazzella et al. 1989). Leaf epiphytes may account for up to $30 \%$ of the canopy biomass of $P$. oceanica (Mazzella \& Ott 1984), support a substantial community of micro- and macrograzers (Orth \& Van Montfrans 1984) and display high species diversity (Boero 1981, Mazzella et al. 1989). Encrusting red or brown algae, filamentous algae, encrusting and erect bryozoans, hydroids and foraminifera are some of the most common morphological groups found $P$. oceanica blades (Pardi et al. 2006). The abundance and wide species composition of these epiphytes support most of the herbivores that inhabit seagrass patches (Kitting et al. 1984, Nichols et al. 1985, Gleason 1986, Dauby 1989).

The melanogenic marine bacterium Marinomonas mediterranea displays a rich secondary metabolism. It expresses 2 different growth-phase-regulated polyphenol oxidases, a tyrosinase and a laccase (Lucas-Elío et al. 2002). The tyrosinase is involved in melanin synthesis using tyrosine as substrate (LópezSerrano et al. 2004). In addition, M. mediterranea synthesizes an antibacterial protein, marinocine, which shows activity against both gram-positive and gram-negative bacteria. The antimicrobial activity of marinocine is due to the hydrogen peroxide generated by its lysine oxidase activity (Gómez et al. 2006). Contrary to $M$. mediterranea, $M$. posidonica neither synthesizes melanin nor expresses an extracellular lysine oxidase (Espinosa et al. 2010). M. posidonica, which has been isolated only from the surface of $P$. oceanica, could, however, still play an important role in influencing plant growth if it facilitates other beneficial bacterial species or secretes nutritional substances of benefit to the host.

We tested the hypothesis that the bacteria Marinomonas mediterranea (Solano et al. 1997) and $M$. posidonica (Lucas-Elío et al. 2010), which form part of the microbiota on Posidonia oceanica, stimulate seagrass growth, inhibit seagrass epiphytes and influence epiphyte community structure on seagrass.

Our aim was to study the effects of both the bacterial species on the leaf growth and the epiphyte community established on Posidonia oceanica seedlings.

\section{MATERIAL AND METHODS}

\section{Bacterial strains}

Marinomonas mediterranea MMB-1 (ATCC 700492) and $M$. posidonica IVIA-Po-181 (NCIMB 14433) were routinely grown in Marine Broth or Marine Agar 2216.

\section{Growth assay}

Posidonia oceanica fruits were collected at Hornillo Bay (Murcia, SE Spain) in April and May 2008. Forty fruits were sterilized in $70 \%$ ethanol and sodium hypochlorite (30:70) for $30 \mathrm{~min}$ and then rinsed 3 times in sterile distilled water. After sterilization, all the seeds were extracted from the fruits and individually germinated in glass bottles with $150 \mathrm{ml}$ of solid agar substrate. The solid substrate was prepared from sterilized bidistilled water, $8 \%$ bacteriological agar and marine salt (PRODAC) $\left(36 \mathrm{~g} \mathrm{l}^{-1}\right)$, following Balestri et al. (1998). All cultures were maintained in a Versatile Environmental Test Chamber (Sanyo MLR-351) at $20 \pm 1^{\circ} \mathrm{C}$ with a photoperiod of $16 \mathrm{~h}$ light:8 h dark (PAR $90 \mu \mathrm{mol} \mathrm{m}{ }^{-2} \mathrm{~s}^{-1}$ ). Two weeks after plantation in agar, $200 \mathrm{ml}$ of artificial seawater (prepared from bidistilled water and the abovementioned marine salt, $36 \mathrm{~g} \mathrm{l}^{-1}$ ) was added to every bottle. The germinated seeds (henceforth referred to 


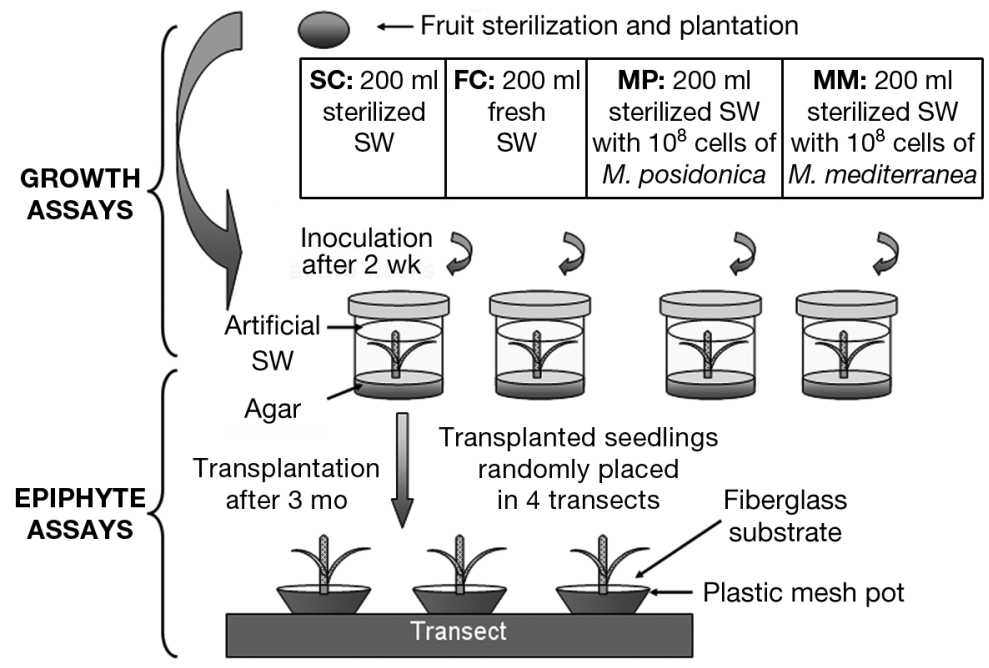

Fig. 1. Diagram of the test arrangement (growth and epiphyte assays). $\mathrm{SW}=$ seawater, $M .=$ Marinomonas

as seedlings) had a single rhizome with 2 leaves (mean leaf area: $1.17 \mathrm{~cm}^{2}$ ) and 1 root.

Four treatments were developed $(\mathrm{n}=8$ seedlings per treatment): seedlings inoculated with $10^{8}$ cells of Marinomonas mediterranea or M. posidonica diluted in $2 \mathrm{ml}$ of sterilized seawater (MM and MP treatments, respectively), and seedlings to which $2 \mathrm{ml}$ of sterilized seawater (sterile control) or fresh seawater (field control) was added (SC and FC treatments, respectively) (Fig. 1). Fresh seawater was collected from Hornillo Bay (Murcia, SE Spain). The SC treatment was used to check the plant growth without bacterial influence whereas the FC treatment was used to compare the influence of the complex interactions of the marine bacterial communities. All the seedlings were incubated detailed above. Plating confirmed that inoculations were successful for each of the bacterial treatments. Tubes in which contamination was observed were eliminated, so that a total of 32 seedlings were used. Three months after inoculation in the laboratory, the leaf area of every seedling was measured with a ruler.

\section{Epiphyte assay}

In July 2008, after 3 mo in the laboratory, seedlings were transplanted to the field to an unvegetated patch of dead rhizomes at $13 \mathrm{~m}$ depth in Hornillo Bay. Prior to transplant, each seedling was transferred from its glass bottle to a separate plastic mesh pot $(8 \mathrm{~cm}$ high $\times 8 \mathrm{~cm}$ diameter) with fiberglass as substrate. The pots were labelled and transported in a plastic container $(200$ l) with sterile seawater and an air pump to the field area $(2 \mathrm{~h}$ from the laboratory). The pots with the seedlings were taken to the sea floor and buried in sediment by SCUBA divers. Pots of the 4 treatments were randomly placed every $2 \mathrm{~m}$ along 3 transects. Herbivores were not excluded to avoid caging effects on leaf macroepiphytes. Macroalgal epiphytes were examined after 90 d (September 2008) on the most external leaf of each seedling to ensure that the analysis focused on mature assemblages (Vanderklift \& Lavery 2000, Buia et al. 2003, Pardi et al. 2006).

The top $10 \mathrm{~cm}$ (from the tip) of seagrass leaves were examined for macroalgal epiphytes under a dissecting microscope fitted with a grid of 100 squares. The macroalgal epiphytes were assigned to morphological groups (filamentous, red crustose, brown crustose, green crustose, red corticated, brown corticated, foliose and articulated calcareous algae) according to Steneck \& Dethier (1994). Functional groupings of algae are based on anatomical and morphological characteristics that correspond to ecological conditions. The abundance of each morphological group was obtained by examining 5 visual fields of $1 \mathrm{~cm}^{2}$ on the upper surface of the leaf and recording the presence or absence of that taxon within 9 squares per visual field, as a total of $9 \times 5=45$ squares examined. This was considered a sufficient sample size as the cumulative frequency of epiphyte species had reached a plateau at that number of visual fields (species-area curve). The total area examined for epiphytes was $5 \mathrm{~cm}^{2}$, following the methodology of Pardi et al. (2006) and Piazzi et al. (2004). A percentage cover of each morphological group was calculated by determining the proportion of squares out of the total (45) in which it was present.

\section{Data analyses}

Differences in leaf area among the 4 treatments of the laboratory growth assay were compared using a one-way ANOVA. Prior to ANOVA, data were tested using a Kolmogorov-Smirnov test for normality and a Cochran test for homogeneity of variance $(\alpha=0.05)$. After ANOVA, differences between specific treatments were determined with a Tukey's honestly significant difference (HSD) post hoc test $(\alpha=0.05)$.

PRIMER (version 6; Clarke \& Warwick 2001) was used to examine differences in epiphyte communities among treatments of the field experiment. Hierarchi- 
cal cluster analysis and multidimensional scaling (MDS) of Bray-Curtis similarities among fourth-root transformed data were used to compare epiphyte community composition between treatments. Similarity percentage (SIMPER) analysis (Clarke \& Warwick 2001) was used to identify which species made the greatest contributions to those differences. The ratio of the contribution of each species to average dissimilarity: standard deviation $(>1.3)$ of the BrayCurtis species dissimilarity between 2 samples was used to determine those species that contributed most to the dissimilarity between 2 groups. These species were thus considered good discriminating species (Clarke \& Warwick 2001).

The abundance of epiphyte morphological groups, identified by SIMPER as important contributors to multivariate differences, was compared between treatments, transects and their interaction using a 2way ANOVA.

A 2-way PERMANOVA was used to determine whether significant effects occurred between treatments, transects and if there were any interactive effects between transect and epiphyte community structure (Anderson 2001) with a post hoc pair-wise comparison between treatments ( $p$-values from PERMANOVA analysis were obtained using 9999 permutations). The Bray-Curtis similarity coefficient was employed to construct a similarity matrix from the fourth-root transformed densities of macroepiphytic species recorded for each replicate.

To check that differences in community composition among treatments were not an artifact of the differing leaf areas among treatments (the species-area hypothesis posits an increase in species richness as the area increases; Cain 1938), a Pearson's correlation between leaf area and the number of functional groups of epiphyte present was run on data from all treatments.

\section{RESULTS}

\section{Growth assay}

Microbial inoculation had a clear effect on leaf area $\left(\right.$ ANOVA, $F_{3,28}=6.6, \mathrm{p}=0.002$; Fig. 2). Posidonia oceania leaf area in the MP and FC treatments was larger than in the $\mathrm{MM}$ and $\mathrm{SC}$ treatments $(\mathrm{MP}=\mathrm{FC}>$ $\mathrm{SC}=\mathrm{MM}$; Tukey's HSD post hoc test, $\mathrm{p}<0.05)$. The MM treatment showed no significant differences from the SC treatment, and the MP and FC treatment were similarly statistically indistinguishable from one another (Tukey's HSD post hoc test, $\mathrm{p}>0.05$ ).

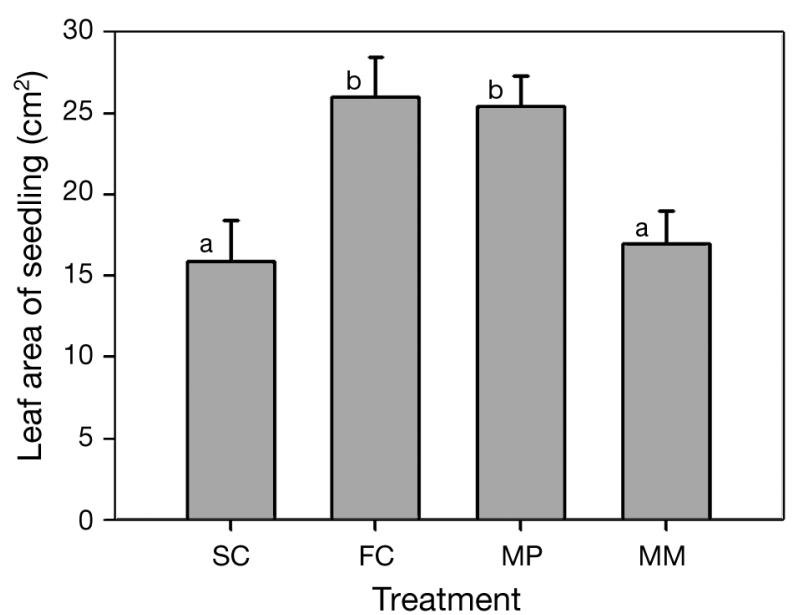

Fig. 2. Posidonia oceanica. Leaf area (mean $+\mathrm{SD}$ ) of seedlings in the laboratory, 3 mo after inoculation. SC: sterilized seawater control; FC: field seawater control; MP: Marinomonas posidonica diluted in sterilized seawater; MM: Marinomonas mediterranea diluted in sterilized seawater. Letters ' $a$ ' and ' $b$ ' refer to 2 statistically different groups (Tukey's HSD post hoc test, $\mathrm{p}<0.05$ )

\section{Epiphyte assay}

Prior to the commencement of the field experiment, epiphytes were absent from the SC, MM and MP treatments. Macroalgae were similarly absent from the FC treatment, although some leaves were covered by biofilm.

By the conclusion of the field experiment, the experimental seedlings were colonized by filamentous, red crustose, brown crustose, green crustose, red corticated, brown corticated, foliose and articulated calcareous algae. MDS showed a different epiphyte community structure between the MM and MP treatments (Fig. 3) but a high dispersion of replicates within the FC and SC treatments, such that the latter 2 treatments could not be clearly distinguished from one another or the other treatments.

The results for a 2-way PERMANOVA showed significant differences in epiphyte community structure between treatments (pseudo- $F_{3,15}=3.17, \mathrm{p}=$ 0.01 ), but there was no difference between transects (pseudo- $F_{2,15}=1.16, p=0.73$ ) or between the interaction of transect location and inoculation treatment (pseudo- $F_{6,15}=0.52, \mathrm{p}=0.73$ ). Pair-wise comparisons among all pairs of inoculation treatments revealed no significant differences except between MP and MM $(t=4.27, \mathrm{p}=0.0003)$. SIMPER analysis indicated that patterns in the epiphyte macroalgal community were driven mainly by differences in the abundance of red crustose, filamentous and red cor- 


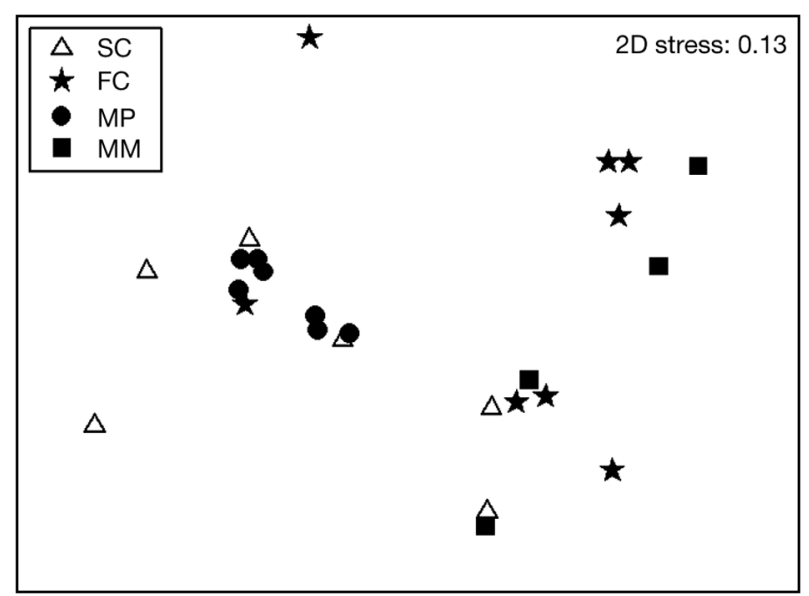

Fig. 3. Posidonia oceanica. Multidimensional scaling biplot of macroepiphyte similarity in seedlings among the 4 inoculation treatments. For abbreviations see legend of Fig. 2

ticated algae (average dissimilarity/standard deviation > 1.3). However, the 2-way ANOVA did not show significant differences in the morphological group of epiphytes between treatment, transect location or their interaction. The abundance of epiphyte growth forms of the different treatments are shown in Table 1.

The Pearson correlation indicated that there was no relationship between leaf area and the number of morphological groups of epiphyte present $\left(\mathrm{r}^{2}=0.02\right.$, $\mathrm{p}=0.48)$.

\section{DISCUSSION}

Microorganisms that are known to have a beneficial effect on terrestrial plants are generally classified into 2 broad groups based on their primary effects: (1) microorganisms with direct growth-promoting effects on plants and (2) biological control agents that indi-

Table 1. Posidonia oceanica. Abundance of epiphyte growth forms found on seedlings $90 \mathrm{~d}$ after transplantation of the 4 treatments (means $\pm \mathrm{SE}$ ). For abbreviations see legend of Fig. 2

\begin{tabular}{|lcccc|}
\hline Epiphyte growth form & SC & FC & MP & MM \\
\hline Filamentous & $3.27 \pm 0.67$ & $3.16 \pm 1.19$ & $3.82 \pm 0.57$ & $3.80 \pm 0.98$ \\
Brown corticated & $0.42 \pm 0.17$ & 0 & 0 & $0.16 \pm 0.13$ \\
Red corticated & $0.52 \pm 0.35$ & $1.2 \pm 0.62$ & $1.45 \pm 0.45$ & $0.26 \pm 0.26$ \\
Brown crustose & $0.05 \pm 0.05$ & $0.03 \pm 0.03$ & 0 & $0.03 \pm 0.03$ \\
Red crustose & $5.12 \pm 0.84$ & $4.86 \pm 1.23$ & $7.22 \pm 0.20$ & $4.50 \pm 1.47$ \\
Green crustose & $0.07 \pm 0.07$ & 0 & 0 & 0 \\
Foloiose & $0.30 \pm 0.19$ & $0.1 \pm 0.06$ & $0.27 \pm 0.18$ & 0 \\
Articulate calcareous & $0.17 \pm 0.175$ & 0 & 0 & 0 \\
\hline
\end{tabular}

rectly assist with plant productivity through the control of plant pathogens. The growth assay with seedlings cultured in sterilized media confirmed that inoculation with Marinomonas posidonica enhanced leaf growth in Posidonia oceanica compared with the sterile control with no bacterial strain added. In contrast, inoculation with $M$. mediterranea did not have a stimulatory effect on leaf growth. No significant differences were observed in leaf growth between the $M$. mediterranea treatment (MM) and the sterile control (SC), suggesting that the stimulatory effect on growth from $M$. posidonica did not occur with $M$. mediterranea. However, effects on growth similar to those observed with $M$. posidonica were observed when non-sterilized seawater was added (FC treatment), suggesting that some microorganisms from the seawater sample were able to colonize seedlings, thereby producing a stimulatory effect similar to the M. posidonica treatment (MP).

Several mechanisms could explain the influence of bacterial strains on Posidonia oceanica seedlings: (1) they play a 'protective' role, releasing chemicals that prevent biofouling by other organisms (Armstrong et al. 2001, Rao et al. 2005); (2) they indirectly assist plant productivity through the control of plant pathogens (Carisse et al. 2003); (3) they favour growth of organisms that are beneficial to the plant; and (4) they liberate metabolites or nutrients that induce plant growth. Because the experiments were carried out under sterile conditions without influence of pathogens or fouling organisms, mechanisms 1, 2 and 3 can be excluded. It is possible that Marinomonas posidonica secreted metabolites or nutrients that favour seedling growth. However, more information on the metabolic capacities of $M$. posidonica and M. mediterranea is needed to identify the exact influence on plant growth.

The epiphyte assay demonstrated that macroalgal epiphyte communities responded to the bacteria present on seagrass. Patterns in the epiphyte macroalgal community were driven mainly by changes in the abundance of red crustose, filamentous and red corticated algae, which were more abundant in the Marinomonas posidonica treatment (MP).

Differences in epiphyte community structure between the Marinomonas posidonica (MP), the M. mediterranea (MM) and the sterile control (SC) treatments could be also explained by the greater leaf area of the MP treatment (species-area hypothesis). 
However, the results of the Pearson test of linear correlation between leaf area and the number of morphological groups do not support this hypothesis. This suggests that differences in epiphyte community structure between microbial treatments were due to direct effects of the microbes and not the indirect effect of changes in the blade size, resulting from microbial effects on growth rate.

Previous studies have found high variability in the epiphytes on leaves of Posidonia oceanica (Piazzi et al. 2004, 2007) and other seagrass species (Vanderklift \& Lavery 2000) at a scale of metres. This smallscale variability may be influenced by differences in shoot density and the characteristics of the canopy, which affect light intensity and water movement (Gambi et al. 1989), local hydrodynamic flows that affect the dispersal, settlement and recruitment of propagules (Trautman \& Borowitzka 1999, Vanderklift \& Lavery 2000), or the role of biotic interaction, such as grazing pressure and the influence of established assemblages on potential recruitment (Mazzella \& Russo 1989).

In conclusion, the laboratory analysis with sterile seedlings of the seagrass Posidonia oceanica showed that inoculation with the bacteria Marinomonas posidonica enhances leaf growth. In contrast, seedlings inoculated with $M$. mediterranea did not show significant differences from sterile seawater controls. The beneficial effects of microorganisms are well known from terrestrial ecosystems, where they promote plant productivity, but no corresponding effects on marine plants have been described. This study demonstrates that microorganisms can also promote plant productivity in marine ecosystems. Inoculation with $M$. posidonica induced changes in epiphyte structure and can be expected to have a regulatory effect on macroepiphytic community structure, especially when this bacterium is predominant on the seagrass. This supports the idea that the inoculation of seedlings with bacteria could influence the establishment of the epiphyte community. The effect of $M$. posidonica could have a direct application in seagrass restoration programmes with seedlings with $P$. oceanica.

Acknowledgements. Funds for this study were provided by the research grant 116/SGTB/2007/1.3 of the Ministerio de Medio Ambiente, Rural y Marino of Spain. We thank CULMAREX S.A. group for SCUBA diving assistance, and Francisco Navarrete and Javier Lloret Barba for help during field and laboratory assays. This research was further facilitated by a grant to D.C. from the Ministerio de Ciencia e Innovación Español, Programa Nacional de Formación de Profesorado Universitario, Spain.

\section{LITERATURE CITED}

Anderson MJ (2001) A new method for non-parametric multivariate analysis of variance. Austral Ecol 26:32-46

> Armstrong, Yan L, Boyd KG, Wright PC, Burgess JG (2001) The symbiotic role of marine microbes on living surfaces. Hydrobiologia 461:37-40

Avis TJ, Gravel V, Antoun H, Tweddell RJ (2008) Multifaceted beneficial effects of rhizosphere microorganisms on plant health and productivity. Soil Biol Biochem 40: 1733-1740

Balestri E, Piazzi L, Cinelli F (1998) In vitro germination and seedling development of Posidonia oceanica. Aquat Bot 60:83-93

> Bhadury P, Wright PC (2004) Exploitation of marine algae: biogenic compounds for potential antifouling applications. Planta 219:561-578

Boero F (1981) Systematics and ecology of the hydroid population of the two Posidonia oceanica meadows. PSZNI: Mar Ecol 2:181-197

Buia MC, Gambi MC, Dappiano M (2003) I sistemi a fanerogame marine. Biol Mar Mediterr 10:145-198

Cain SA (1938) The species-area curve. Am Midl Nat 19: $573-581$

Callow ME (2000) Algal biofilms. In: Evans LV (ed) Biofilms, recent advances in their study and control. Overseas Publishing Associates (UK), Amsterdam, p 189-210

Carisse O, Bernier J, Benhamou N (2003) Selection of biological agents from composts for control of damping-off of cucumber caused by Pythium ultimum. Can J Plant Pathol 25:258-267

Clarke KR, Warwick RM (2001) Change in marine communities: an approach to statistical analysis and interpretation, 2nd edn. PRIMER-E, Plymouth, UK

$>$ Dauby P (1989) The stable carbon isotope ratios of benthic food webs of the Gulf of Calvi, Corsica. Cont Shelf Res 9: 181-195

> Egan S, Thomas T, Kjelleberg S (2008) Unlocking the diversity and biotechnological potential of marine surface associated microbial communities. Curr Opin Microbiol 11:219-225

Ellis RJ, Timms-Wilson TM, Beringer JE, Rhodes D, Renwick A, Stevenson L, Bailey MJ (1999) Ecological basis for biocontrol of damping-off disease by Pseudomonas fluorescens 54/96. J Appl Microbiol 87:454-463

> Espinosa E, Marco-Noales E, Gómez D, Lucas-Elío P and others (2010) Taxonomic study of Marinomonas strains isolated from the seagrass Posidonia oceanica, with descriptions of Marinomonas balearica sp. nov. and Marinomonas pollencensis sp. nov. Int J Syst Evol Microbiol 60:93-98

Gambi MC, Giangrande A, Chessa LA, Manconi R, Scardi $M$ (1989) Distribution and ecology of polychaetes in the foliar stratum of a Posidonia oceanica bed in the bay of Porto Conte (N.W. Sardinia). In: Boudouresque CF, Meisnesz A, Fresi E, Gravez V (eds) International Workshop on Posidonia oceanica Beds II. GIS Posidonie, Marseille, p 145-156

Givskov M, de Nys R, Manefield M, Gram L and others (1996) Eukaryotic interference with homoserine lactonemediated prokaryotic signalling. J Bacteriol 178: 6618-6622

> Gleason DF (1986) Utilization of salt marsh plants by postlarval brown shrimp: carbon assimilation rates and food preferences. Mar Ecol Prog Ser 31:151-158 
Gómez D, Lucas-Elío P, Sanchez-Amat A, Solano F (2006) A novel type of lysine oxidase L-lysine- $\varepsilon$-oxidase. Biochim Biophys Acta 1764:1577-1585

Kitting CL, Fry B, Morgan MD (1984) Detection of inconspicuous epiphytic algae supporting food webs in seagrass meadows. Oecologia 62:145-149

López-Serrano D, Solano F, Sanchez-Amat A (2004) Identification of an operon involved in tyrosinase activity and melanin synthesis in Marinomonas mediterranea. Gene 342:179-187

Lucas-Elío P, Solano F, Sanchez-Amat A (2002) Regulation of polyphenol oxidase activities and melanin synthesis in Marinomonas mediterranea: identification of ppoS, a gene encoding a sensor histidine kinase. Microbiology 148:2457-2466

Lucas-Elío P, Marco-Noales E, Espinosa E, Ordax M and others (2010) Marinomonas alcarazii sp. nov., M. rhizomae sp. nov., $M$. foliarum sp. nov., M. posidonica sp. nov. and $M$. aquiplantarum sp. nov., isolated from the microbiota of the seagrass Posidonia oceanica. Int J Syst Evol Microbiol 61:2191-2196

Maki JS (1999) The infuence of marine microbes on biofouling. In: Fingerman M, Nagabhushanam R, Thompson MF (eds) Biofilms, Bioadhesion, Corrosion and Biofouling, Vol. 3. Science Publishers, New Dehli, p 147-171

Manefield M, Welch M, Givskov M, Salmond GP, Kjelleberg S (2001) Halogenated furanones from the red alga, Delisea pulchra, inhibit carbapenem antibiotic synthesis and exoenzyme virulence factor production in the phytopathogen Erwinia carotovora. FEMS Microbiol Lett 205:131-138

Matz C, Kjelleberg S (2005) Off the hook-how bacteria survive protozoan grazing. Trends Microbiol 13:302-307

Mazzella L, Ott JA (1984) Seasonal changes in some features of Posidonia oceanica (L.) Delile leaves and epiphytes at different depths. In: Boudouresque CF, Juedy de Grissac A, Olivier J (eds) First international workshop on Posidonia oceanica beds. G.I.S. Posidonie Publ Fr 1:119-127

Mazzella L, Russo GF (1989) Grazing effect of two Gibbula species (Mollusca, Archeogasteropoda) on the epiphyte community of Posidonia oceanica leaves. Aquat Bot 35: $357-373$

> Mazzella L, Scipione MB, Buia MC (1989) Spatio-temporal distribution of algal and animal communities in a Posidonia oceanica meadow. PSZNI: Mar Ecol 10:107-129

Nichols PD, Klump DW, Johns RB (1985) A study of food chains in seagrass communities. III. Stable carbon isotope ratios. Aust J Mar Freshw Res 36:683-690

Ongena M, Daayf F, Jacques P, Thonart P, Benhamou N, Paulitz TC, Bélanger RR (2000) Systemic induction of phytoalexins in cucumber in response to treatments with fluorescent pseudomonads. Plant Pathol 49:523-530

> Ongena M, Giger A, Jacques P, Dommes J, Thonart P (2002) Study of bacterial determinants involved in the induction of systemic resistance in bean by Pseudomonas putida BTP1. Eur J Plant Pathol 108:187-196

Orth JR, Van Montfrans J (1984) Epiphytes-seagrass relationships with an emphasis on the role of micrograzing: a review. Aquat Bot 18:43-69

Editorial responsibility: Matthias Seaman,

Oldendorf/Luhe, Germany
Pardi G, Piazzi L, Balata D, Papi I, Cinelli F, BenedettiCecchi L (2006) Spatial variability of Posidonia oceanica (L.) Delile epiphytes around the mainland and the islands of Sicily (Mediterranean Sea). PSZNI: Mar Ecol 27:397-403

Pasmore M, Costerton JW (2003) Biofilms, bacterial signaling, and their ties to marine biology. J Ind Microbiol Biotechnol 30:407-413

Piazzi L, Balata D, Cinelli F, Benedetti-Cecchi L (2004) Pattern of spatial variability in epiphytes of Posidonia oceanica. Differences between a disturbed and two references locations. Aquat Bot 79:345-356

Piazzi L, De Biasi AM, Balata D, Pardi G and others (2007) Species composition and patterns of spatial variability of morphological forms of macroalgal epiphytic assemblages of the seagrass Posidonia oceanica. Vie Milieu 57: 1-9

Rao D, Webb JS, Kjelleberg S (2005) Competitive interactions in mixed-species biofilms containing the marine bacterium Pseudoalteromonas tunicata. Appl Environ Microbiol 71:1729-1736

- Richmond MD, Seed R (1991) A review of marine macrofouling communities with special reference to animal fouling. Biofouling 3:151-168

$>$ Rodríguez SR, Ojeda FP, Inestrosa NC (1993) Settlement of benthic marine invertebrates. Mar Ecol Prog Ser 97: 193-207

> Selosse MA, Richard F, He X, Simard SW (2006) Mycorrhizal networks: des liaisons dangereuses? Trends Ecol Evol 21: 621-628

Solano F, García E, de Egea EP, Sanchez-Amat A (1997) Isolation and characterization of strain MMB-1 (CECT 4803), a novel melanogenic marine bacterium. Appl Environ Microbiol 63:3499-3506

St-Arnaud M, Hamel C, Vimard B, Caron M, Fortin JA (1996) Enhanced hyphal growth and spore production of the arbuscular mycorrhizal fungus Glomus intraradices in an in vitro system in the absence of host roots. Mycol Res 100:328-332

Steneck RL, Dethier MN (1994) A functional group approach to the structure of algal-dominated communities. Oikos 69:476-498

> Thrane C, Nielsen TH, Nielsen MN, Sørensen J, Olsson S (2000) Viscosinamide producing Pseudomonas fluorescens DR54 exerts a biocontrol effect on Pythium ultimum in sugar beet rhizosphere. FEMS Microbiol Ecol 33: 139-146

> Trautman DA, Borowitzka MA (1999) Distribution of the epiphytic organisms on Posidonia australis and P. sinuosa, two seagrasses with differing leaf morphology. Mar Ecol Prog Ser 179:215-229

> Vanderklift MA, Lavery PS (2000) Patchiness in assemblages of epiphytic macroalgae on Posidonia coriacea at a hierarchy of spatial scales. Mar Ecol Prog Ser 192: 127-135

> Wahl M (1989) Marine epibiosis. I. Fouling and antifouling: some basic aspects. Mar Ecol Prog Ser 58:175-189

Young LY, Mitchell R (1973) The role of microorganisms in marine fouling. Int Biodeterior Bull 9:105-109

Submitted: July 20, 2011; Accepted: February 14, 2012

Proofs received from author(s): May 23, 2012 